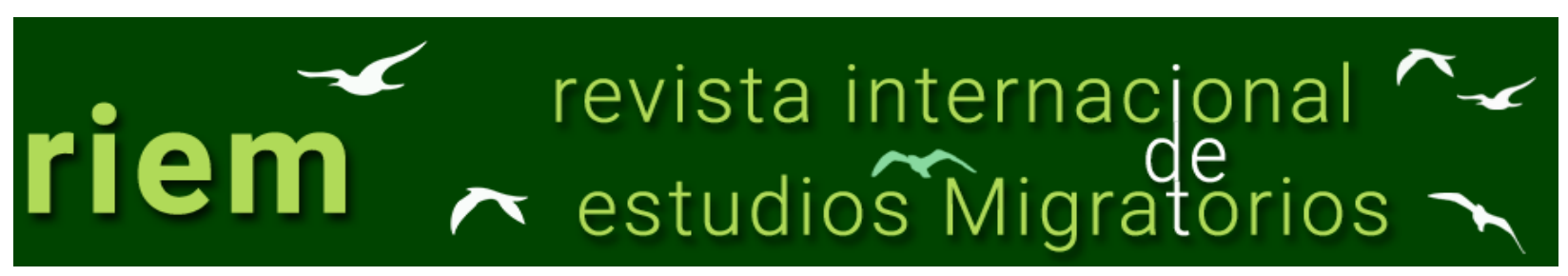

ISSN: 2173-1950

\title{
Refugees and asylum seekers' emotions in migration studies
}

\author{
Basem Mahmud ${ }^{1}$
}

\begin{abstract}
This paper reviews the theoretical and empirical studies on emotions in migration studies to determine the state of the art as well as to identify gaps. In addition to the three main approaches to understanding forced migrants' emotional lives (extraordinary, everyday encounters, and therapeutic), this paper identifies different types of empirical research informed by these theoretical perspectives. They focus on: the impact of the context of migration, emotions during a specific stage of the journey, and the emotions, values, and traditions that forced migrants bring with them to the destination country. This literature review led to determining the most relevant tendencies and considerations. Due to the dominance of the therapeutic and extraordinary approaches, there is a need to (1) explore further the role of emotions in forced migration; (2) look at how forced migrants construct their emotions without losing the context (where, why and when); (3) investigate other functions of emotions or to ask how forced migrants make sense of their experience of violence, torture...etc.; (4) take into consideration the whole journey from beginning to end; (5) develop a theory based on empirical data which explains the interaction between emotions and belonging.
\end{abstract}

Keywords: sentiment, feeling at home, belonging, forced migration.

${ }^{1}$ Marie Skłodowska-Curie fellow, Universidad de Granada, Granada, España. basem@ugr.es. 


\section{Las emociones de los refugiados y solicitantes de asilo en los estudios de migración}

Resumen: Este artículo revisa los estudios teóricos y empíricos sobre las emociones en los estudios de migración para determinar el estado del arte, así como para identificar brechas. Además de los tres enfoques principales para comprender la vida emocional de los migrantes forzados (extraordinaria, encuentros cotidianos, y terapéutica), el presente artículo identifica diferentes tipos de investigación empírica informada por estas perspectivas teóricas. Se centrarán en: El impacto del contexto de la migración, las emociones durante una etapa específica del viaje, y las emociones, valores y tradiciones que los migrantes traen al destino. Esta revisión de la literatura llevó a determinar las tendencias y consideraciones más relevantes. Debido al dominio de los enfoques terapéuticos y extraordinarios, es necesario (1) explorar más a fondo el papel de las emociones en la migración forzada; (2) observar cómo los migrantes forzados construyen sus emociones sin perder el contexto (dónde, por qué y cuándo); (3) investigar otras funciones de las emociones o preguntar cómo los migrantes forzados hacen sentido de su experiencia de violencia, tortura ... etc.; (4) tener en cuenta todo el viaje de principio a fin; (5) desarrollar una teoría basada en datos empíricos que explique la interacción entre las emociones y la pertenencia.

Palabras Clave: sentimientos, sentirse en casa, pertenencia, migración forzada. 


\section{Introduction}

Migration is generally studied using macro-structural or micro-rational approaches (mostly focused on migration decision-making) rather than subjective experiences such as psychological and cultural dimensions, emotions, values, and social interactions. However, all of us have seen pictures and videos in the news covering the so-called refugee crisis (after 2014), of people attacked in their homes by the repressive apparatus of their 'nation-state.' Thousands were killed, and others were forced to flee 'home.' Those who arrived in Europe were received in different ways; sometimes with welcome, sympathy, or solidarity and others with persecution and discrimination. As a migrant, all of this directed my interest in the forced migrant's emotions (e.g., perception of empathy/or humiliation) and its impact on his feeling of belonging toward the places and society from which he fled (among them home) and those where he settled. This is how I became interested in studying the experiential dimensions of the forced migration phenomena. This paper aims to examine how migration literature addresses forced migrants' emotions. In general, forced migrants are treated as a mere subgroup of "migrant" and this applies as well to research on their emotions. When a distinction is made, refugees are presented as being more traumatized and in need of help. Therefore, this paper divided in four sections: The first two sections review emotions in migration studies in general, and explores insights on forced migration within this broader framework. The last two sections deal specifically with the literature dedicated exclusively to cases of forced migration. As a whole, this research shifts the attention toward more research on forced migrants' emotions and its role in integration by looking at the broader functions of emotions beyond the therapeutic approach. It therefore provides useful information for researchers, policymakers, and professionals who seek to better understand forced migration and resettlement in the destination country.

\subsection{The neglected emotional dimension in classical migration theories}

Since the end of the nineteenth century, migration studies have not only increased in volume but also the perspectives have changed over time and have used different concepts to understand why international migration occurs. For example, there are economic theories based on a macro-analytical perspective. These focus on structural issues related to objective conditions that function as 'push' and 'pull' factors for migration and examine questions like labor demand or differences in wage rates and employment conditions between countries. These include classical and neoclassical macro-economics (Lewis, 1954; Ranis \& Fei, 1961; 
Todaro, 1969), dual market labor theory (Piore, 1979), and world systems theory (Wallerstein, 1974). However, this approach failed to explain migration between countries with similar economic development or to answer questions about the volume of migration from a particular country to a specific country (e.g., Moroccans in France), or why a country with similar structural conditions to another country has significantly less migration. Also, it leaves no room for human agency (see Boswell, 2002; Castles et al., 2014, p. 31; Wimalaratana, 2016).

Micro-level theories focus on the individual and his desires and expectations. Here, the decision-making has to do with rational calculation (benefit vs. costs of migration), as in Sjaastad's (1962) neoclassical economics approach. The value-expectancy model focuses on the values people ascribe to an expected outcome (De Jong et al., 1983; De Jong \& Fawcett, 1981). There are also behavioral models which are concerned with the personality of the individual and its interaction with triggers or stimuli (Courgeau, 1995). These theories help to observe the agency of the individual, but they ignore the structural issues. Furthermore, they are focused on rational action, not on affective action.

Meso-level theories attempt to integrate the micro and macro levels. By focusing on social ties or networks, it links structures with individual decision-making. Network theory argues that people migrate based on their previous contacts; they go where they already know someone (Boyd, 1989; Massey et al., 1993). Network theory was able to provide more insight into the push factors and explain different aspects of migration phenomena; choice of destination (Banerjee, 1983; Faist, 1997); conflicts or tensions in social ties in home countries as a reason for migration, or families encouraging some members to migrate (Hugo, 1981, p. 196).

Therefore, the interest in emotions during the migration process was absent because the focus was either on structural issues or rational choice theories. Social ties are studied in relation to decision-making and adapting process (Hagen-Zanker, 2008; Richmond, 1988), without exploring in-depth the emotional dimension of migration. The question of the significance of emotions for understanding migration has been therefore neglected in these theories. However, the attempt to classify migrants has led to some interest in migrants' emotions. Researchers tend to define the types of migration, in general, based on the degrees of autonomy in decision-making processes: Richmond (1988) developed a typology of migration where he considers the decision-making process alongside socio-political factors; 
Proactive migrants include retirees, transients, returnees, family reunions, and emigrants. Reactive migrants include refugees, forcibly-displaced people, slaves, forced laborers, exiles and mass expellees. Between these two extremes, there is a variety of people who cross borders having low degrees of autonomy but, to some extent, having both the time and possibility to choose their destination. Petersen (1958) distinguished between forced and impelled migrants; the latter having some amount of power to leave or not to leave, while the former is expulsed by an external power such as a state. Kunz's kinetic model (1973) distinguished between two different forced refugee movements; anticipatory and acute. Anticipatory asylum seekers leave to some extent prepared because they anticipate the threat and danger and leave before the total deterioration of the situation. They also know their destination. However, the acute asylum seeker leaves amidst an already deteriorated condition, e.g., under military pressure, usually has not prepared for their departure and their destination is not clear. They are continuously looking for a safe place and arrive at the final destination after time spent inside their own country first (in some cases) and later in other asylum-countries (possibly neighboring countries).

Kunz's kinetic model highlights the issue of emotion during a specific period of this process. In the midway-to-nowhere scenario, the asylum seeker has found shelter and is now in a "spiritual, spatial, temporal and emotional equidistant no man's land of midwayto-nowhere and the longer he remains there, the longer he becomes subject to its demoralising effects" (Kunz, 1973, p. 133). While these demoralizing effects grow, the asylum seekers face three crucial possible decisions; return home, stay in the first asylum-country, or seek out new land. Nevertheless, over time these three options may become just two or perhaps one (no choice): while the reasons for fleeing the country remain, the material means of existence are limited. Depending on the asylum seeker's positive or negative interpretation, even the smallest sign or piece of news could foster great hope or disappointment, which in turn influences their decision-making; to return, stay, or move to a new place. However, the role of this experience in the refugee's future settlement still needs to be explored. Some scholars have demonstrated the vital role of specific emotions; e.g., the role of grief among Lithuanian refugees (Baškauskas, 1981). Jensen (1966, p. 58) insists on the importance of understanding the emotional state of the refugee upon arrival in the asylum country (hate, anger, fear...etc.) as it pertains to his country of origin because it could play a role in resettlement. These early considerations of refugees and asylum seekers' emotions point out the critical role of emotions in the forced migration experience. However, 
in these theories, emotion was not used as an analytical concept to study the forced migration experience. That will happen later with the consolidation of the transnationalism approach.

1.2. Transnationalism and translocality: home and belonging as key concepts in the migrant's emotional lives

The definition of transnationalism in migration studies appeared for the first time in the work of Glick Schiller, and Blanc-Szanton; Transnationalism: A New Analytic Framework for Understanding Migration (1992). Transnationalism is defined as "the process by which immigrants forge and sustain multi-stranded social relations that link together their society of origin and settlement" (Basch et al., 1994, p. 7). At approximately the same time, the affective turn took place in the social sciences (early to mid-1990s). The traditional image of migrants changed. Here, the migrant is neither viewed as a person who leaves his land and comes to another to find a new "home" nor as a person who only comes to work temporarily to return at a later point in time. In the framework of transnationalism, he is seen as a person who develops networks, connections, patterns of living, and activities beyond both the country of origin and destination. In this way, the construction of belonging and the emotional attachment to the home country and destination started to become a central issue in migration studies.

Many studies have demonstrated the close connection between emotions and belonging in migration, both explicitly and implicitly. Emotions are essential for understanding various social phenomena: emotional labor performed by transnational workers, transnational childhoods, transnational care, return migrant visits, transnational family reunions, longing, and the emotionalized "national" family and migration writings (Herrero-Arias et al., 2020; See Skrbis, 2008). Furthermore, emotions are necessary for understanding migrants' subjectivities, as Walsh (2012) demonstrates in her research about British migrants' emotions in Dubai. Wang's (2016) study about first-generation Chinese migrants in New Zealand shows that in migration, emotions and home-construction interact with each other in an "amplified and more dramatic way." The term "emotional transnationalism' appeared in Diane Wolf's work (2002) There's No Place Like 'Home': Emotional Transnationalism and the Struggles of Second-generation Filipinos. This concept "reflects emotional attachments and belonging to the nation of ancestors" (Chaloyan, 2017, p. 41). 
More recently, a new approach emerged which argues that the transnationalism approach should be reviewed. The newer approach, 'translocality,' is defined as 'groundedness' during movement, which includes everyday movements that are not necessarily transnational (K Brickell \& Datta, 2012, p. 4). It therefore becomes necessary to understand the local-local connections, instead of only focusing on the 'national' scale. Translocality is useful for understanding the everyday life of transnational migrants; by drawing attention to the local, it is possible to observe translocal relationships that usually remain, to some extent, invisible when the analysis operates at the level of the nation-state (as is the case with the transnationalism approach). However, it should be made clear that translocality is not opposed to transnationalism. There is no inherent contradiction between them, and in general, translocality can be understood as an intent to move toward more territorialized notions of transnationalism; small-scale transnationalism (Burrell, 2003) or deterritorialization (Appadurai, 1996).

The concept of 'home' as a personal and intimate place has become a central issue in the debate. Wolf's work on 'emotional transnationalism' appeared as a section in a book titled The Changing Face of Home: The Transnational Lives of the Second Generation (2002). Many researchers have engaged other questions about 'home'; what is it, is it 'there' related to the country of origin or 'here', or here and there (Al-Ali \& Koser, 2003; Bonifacio, 2017, p. 89; Falicov, 2005; Kochan, 2016; Leith, 2006; Parsell, 2012; Vaqari, 2020). Translocality led researchers to focus on "the traditional space of the home, family, community, and neighborhood, which are often the immediate site of encounters with 'otherness' and where notions of belonging and attachment are produced.” (Brickell \& Datta, 2012, p. 16) That is to say, to the most significant places, boundaries and spaces for the migrants, with which they must deal in everyday life. Researchers who work within this theoretical approach are keen to consider home as translocal in that, "it is shaped by consumption, remittances, and social networks; by actual home-building, and by a range of connections to other homes in other localities. These homes are the sites where cultural difference and 'otherness' is constructed, lived, and negotiated through the ambiguous relationships between mobility and migration.” (Brickell \& Datta, 2012, p. 14). Liangni Sally Liu's study about new migrants from the People's Republic of China found that identity, senses of belonging, and conceptualization of home are 'intimately connected' (Liu, 2014). With this perspective, belonging comes to be understood not just through a negotiation based on global-local connections, but also through local-local attachments along the migratory route (Datta, 
2011, p. 74). With this in mind, we can ask how migrants build a home, that is the "building of the feeling of being 'at home"' (Hage, 1997). Emotions play a central role in this process (Antoniadou, 2019). For Hage, home building is based on four affective blocks: security, familiarity, community, and a sense of possibility or hope. Also, he argues that nostalgia could be used by migrants to engage in home-building in the here and now, and only when faced with difficult conditions which make home-building impossible, could it convert into homesickness (Hage, 1997).

Based on this dynamic transnational approach, many researchers focus on migrants' agency to observe how they "come up with new concepts of home and belonging, enter into a constructive dialogue with host societies, (attempt to) participate in political discourses as equal partners, and produce innovative cultural artifacts that challenge static concepts of race, national identity, citizenship, gender, age, and other categories of collective identification.” (Kläger \& Stierstorfer, 2016, p. 5). However, in the case of forced migrants, it necessary to review these concepts carefully. Catherine Nolin (2006) found that in the Guatemalan context, the deterritorialization of everyday life is a reality, but a "deterritorialized nation-state" is not. This is the result of the totalitarian regime's ideology that excludes Guatemalan refugees and opponents from the nation-building process. They are not considered as citizens who live outside of the national territory. Mayan groups were socially constructed as being 'less than human' (Nolin, 2006, p. 50). This situation is not an isolated case; many states from which refugees and asylum seekers are coming are controlled by totalitarian regimes, or where nation-state building projects have failed, and other local identities may have had a more important role than the national. Furthermore, refugees in many cases traverse different lands and societies, spending months or even years somewhere else before reaching their destination. They develop different relations to different places, and they face different migration policies, organizations, human smugglers, and of course meet and encounter different societies and local communities. Thus, in the case of transnational refugees, we need to consider the whole journey (Yildiz, 2017, p. 7), or we will lose useful information for understanding how people construct their feelings of belonging in mobility. All of this indicates that home and belonging are two keywords for understanding forced migrants' emotional experience.

1.3. Three approaches to investigate forced migrants emotions; extraordinary, 
Revista Internacional de Estudios Migratorios, 2021, Vol. 11(1), pp. 27-58.

therapeutic, and everyday encounters

As I explained in the previous lines, with the emergence of transnationalism theory, the image of the migrant changed. Furthermore, this change raised more questions about migrants' emotions because now they are seen as people who live connected both to the place of the family and home, as well as to the new place. Nolin's 'refugee transnationalism' incorporates political violence into the concept of transnational migration. It suggests two key shifts; (1) from a focus on connections to a focus on 'ruptures and sutures' of belonging and identity. (2) From 'community identity' to 'transnational social fields' and multi-scaled social relations (Nolin, 2006, p. 182). Also, it should not be limited to the pathological approach that focuses on the mental health problems caused by those emotions that accompany violence - such as shame, humiliation, anger, anxiety, guilt, etc. In a study conducted in Western Australia, Val Colic-Peisker and Farida Tilbury (2003) found that medicalization of the refugee experience may have negative results by pushing refugees into a passive "victim role." Talal Asad (2003) suggests that pain and suffering could also play an essential role in the construction of the actor's agency. Another approach which looks at what people do with emotions could provide a rich understanding of their construction of the sense of belonging; the experience of self-transcendence related to agony or violence leads to new values and value commitments (Joas, 2000). This is due to the close connections between emotions and values or moral judgment, as many scholars argue (Eisenberg, 2000; Haidt et al., 1993; Vishkin et al., 2020; Von Scheve, 2015).

A recent work entitled Belonging and Transnational Refugee Settlement: Unsettling the Everyday and the Extraordinary (2017) questions belonging by focusing on 'the everyday' and 'the extraordinary' in the refugee's experience. In this book, Marlowe (2017) defines 'the extraordinary' as those experiences that often sit "beyond the everyday and which are not necessarily shared by the wider society" (Marlowe, 2017, p. 36). Everyday practices seem to be hidden because they are related to the mundane, ordinary and routine actions of both locals and refugees. The extraordinary, on the other hand, which refers to specific cases of the refugee's experience, becomes an issue of interest for media and public debate as well as much research on migration. This extraordinary representation may become an obstacle to their integration and participation in society. This is because they are often represented as traumatized people. However, this does not mean that the extraordinary cannot provide any benefits for the refugee, especially for their claim of 
recognition (Marlowe, 2017, p. 37). What is essential here is to take into consideration these two different kinds of experience.

Early phases of migration are to some extent full of these extraordinary experiences, but once the refugee is settled the everyday practices predominate. Seen in this way, I agree with Marlowe that refugee resettlement is about protection, while the settlement is about belonging (2017, p. 25). People make sense of their experience, and the extraordinary may still accompany them. The question is how they interpret it during the settlement and how these interpretations interact with their feelings of belonging. Thus, to understand refugees' experience we need to consider the whole story from beginning to end. Furthermore, it is necessary to understand who is defining, what is extraordinary, what is not, and how refugees respond, resist or challenge. That is because these definitions impact the refugee's representations and his life (Marlowe, 2017).

Based on what we have seen until now, we could say that there are three main approaches to investigating forced migrants' emotional lives; (1) the everyday-encounters approach which looks to everyday life to develop questions such as how people give meanings to the world around them, reinterpret it, and make sense from their experience; (2) the therapeutic, where the main interest is the consequences of trauma - which is almost a predefined concept - on the forced migrant's life after the flight; and (3) the extraordinary, which ignores everyday life to focus on the extraordinary, i.e. specific events which refugees and asylum seekers do not share with the society of destination. The last two approaches are the most dominant, and the commonality between them is that they both contribute to the presentation of forced migrants as a 'strange' or 'traumatized' person.

To summarize, I have demonstrated the existence of an early interest in emotions in migration studies in connection with an interest in the forced migration experience. However, many factors have prevented the development of solid theoretical knowledge about forced migrants' emotions. This includes the tendency to approach forced migrants under the umbrella of migrants, and the domination of therapeutic or extraordinary models. Transnational and translocal approaches brought considerably more interest in the emotional lives of the migrants and demonstrated the central role of belonging. In this way, belonging and emotions became essential concepts for understanding the experience of forced migrants. However, the relationship between them remains unclear. As Halse (2018) argues, "emotions play an important part in constructing belonging and social collectivities. 
But emotions-as-belonging can have risky, even dire, effects because emotions can circle back on themselves in ways that reinforce and entrench boundaries, contestation and the politics of belonging" (Halse, 2018, p. 14). Therefore, it is imperative to study the different functions of emotions in constructing belonging/(non)belonging. Even though there is no unified theory, the three approaches presented here are helpful when used critically. Furthermore, some relevant empirical studies could spark new ideas, hypothesis, or questions about this interaction.

\subsection{The intersection between emotions and belonging in forced migration}

In her research about fear among Colombian forced migrants, Pilar Riano-Alcalá (2008) found that fear is "experienced as a continuum that operates as an emotional regime and a structuring feeling that situates the individuals within an economy of affect where powerful, anxious, and sometimes contradictory feelings of uncertainty, anxiety, and hope mediate both the process of reconstructing their lives, and their interactions with the forced migration regime and the host society" (Riaño-Alcalá, 2008, p. 16). At home, they fear violence from the state or other armed forces. Along the way, they fear border guards, authorities in neighboring countries, the risks of sea-travel, militant attacks (bandits along their paths), smugglers, and separation from family. Once they arrive to the destination countries, the fear comes from their inability to communicate due to language deficiencies, from media and the discourse of the political right, as well as from migration policies (Blažytė et al., 2020; Parker, 2020). All of this is associated with emotions of shame, embarrassment, or humiliation. Their emotional management becomes oriented toward protecting the self or family members from these emotions (Wettergren, 2013, p. 136). It is therefore necessary to give special attention to forced migrants' interaction with power; armed groups, police, professionals, smugglers, etc. These are not interactions with 'equals', and are generally related to claiming rights and needs. However, this does not mean that they do not establish meaningful relationships during this process. Indeed, there is also solidarity, empathy, and sympathy (which can be found even with the smugglers who share with them the same boat and destination). Though empathic emotions are essential for belonging (Kale et al., 2020), belonging also depends on feeling safe, feeling at home, and feeling welcome (Eltokhy, 2020; Huizinga \& van Hoven, 2018; Vuolteenaho \& Lyytinen, 2018). The question is therefore how these emotions and the strategies employed to overcome insecurity and fear influence their construction of belonging after leaving home. I 
found four types of empirical studies which investigate forced migrants' emotions and belonging while giving more attention to specific phases of the forced migration journey: context in the home country, on the way, the midway-to-nowhere scenario, and context in the destination country. ${ }^{2}$

The first focuses on forced migrants' lives in the destination country with specific interests in their emotions, values, and tradition (mostly based on the therapeutic and/or the extraordinary approaches); here, refugees are seen as people who suffer from mental health problems because of traumatic events. Their values, religion, and tradition are generally seen as a wall which separates them from the host society. Therefore, I situate this type between therapeutic and extraordinary. Recently, more voices are challenging this view; values and religion are useful for coping with trauma and could be helpful to construct feeling at home in the new society.

A second type focuses on the midway-to-nowhere scenario and raises questions about the emotional state of the asylum seekers once he is in a safe place in transit. It anticipates important changes in his emotions and feelings of belonging. The main interest here is in providing him with psychological support after fleeing a dangerous situation and understanding those changes which occur in his emotions and belonging, especially toward the home country (because at this time, he is still unable to develop a sense of belonging in the new place). Therefore, I situate it between the everyday encounters and therapeutic approaches.

The third type gives special attention to the period during which people move toward a final destination. Here, the focus is mostly on border control, smuggling, and the traumatic experiences which accompany the refugees along their path. Also, this approach is interested in the meaningfulness of this experience in the formation of forced migrants' identities. Therefore, I situate this type between extraordinary and everyday encounters.

The fourth and last type is the contextual. It gives great weight to the context of migration in the home country (we might think about forced migrants who left home after a popular

\footnotetext{
${ }^{2}$ If the midway-to-nowhere scenario is about finding a temporal shelter after leaving home (mostly a camp in a neighboring state), the on-the-way scenario refers to moments after leaving home and before finding this temporary shelter or after losing/moving from it toward the destination country.
} 
uprising or war as distinct from those who left a stable totalitarianism regime) and/or to the context in the destination country (e.g., higher levels of racism mean more ghettos or maintenance of boundaries). In this way, emotions and belonging may differ among people from the same ethnic group or nationality who migrate in different contexts. Despite this vital emphasis on structural issues, many contextual studies have considered the individual and his subjectivity in the process of migration. These generally use any of the three theoretical approaches to study forced migration; everyday encounters, therapeutic, and extraordinary. Figure (1) shows the relationship of each type with the theoretical approach. In the following lines, I present these types in more detail and look at those studies that enable us to make assumptions about the interaction between emotions and belonging even when they are not explicitly mentioned.

Figure 1. Four types of empirical research to investigate forced migrants' emotional lives

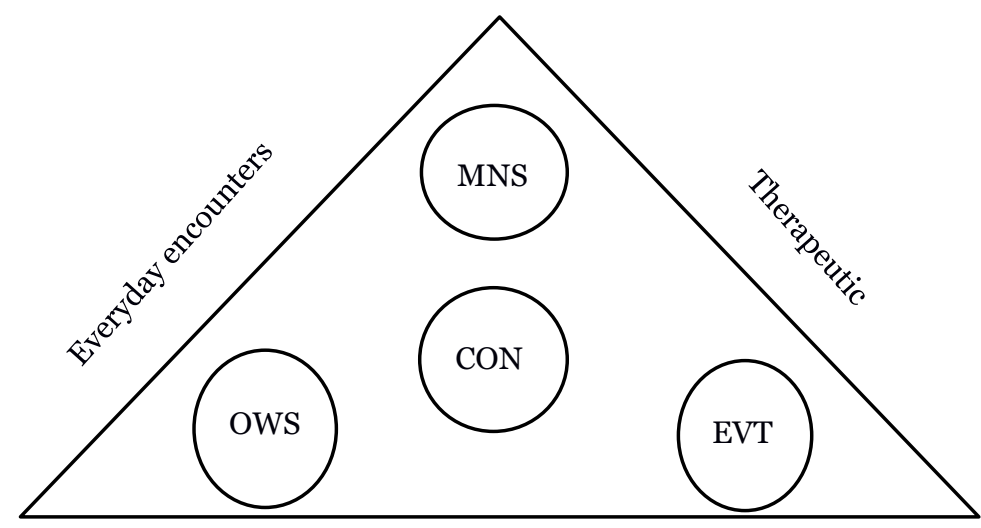

Extraordinary

OWS: On the way scenario

CON: The context of migration

MNS: The midway-to-nowhere scenario

EVT: The Emotions, Values and Tradition which accompany the

Source: Prepared by the author 


\subsubsection{The socio-historical contexts of the country of origin}

Many studies show how different socio-historical contexts of migration lead to various emotional attachments to home (Brown, 2011; Galasińska, 2010; Trew, 2010). Brown (2011) compares two groups of Polish immigrants: one migrating during the post-WWII period and the other after Poland's joining the EU. She found that the emotional connection with the homeland differs between these two groups. There are two different kinds of nostalgia; 3 restorative nostalgia in the post-war group, and reflective nostalgia among the postaccession group. These differences arise from the different role that their country of origin (Poland) played in their life. In a similarly comparative way, after adding a third group (post1989/pre-enlargement immigration), Aleksandra Galasińska (2010) demonstrated how the different socio-historical conditions of migration have influenced the sense of self of Polish migrants who settled in Britain in different periods and how they express their emotions in different ways. She found that gossip became a means of expressing emotions to create boundaries with other groups, or to build an attachment to "our" group, even though they acknowledge the other group as Polish. These roles of emotions in group formation in diaspora become more apparent in the context of conflict. Devlin Trew (2007), in her study about Protestant immigrants from Northern Ireland in Britain, demonstrates how a specific political and historical context such as the Northern Ireland conflict influences the construction of identity among the refugees in the destination country in two directions. First, most of his respondents felt that this conflict "was a significant factor in how they were defined by others." Second, the diaspora space became a place where rival Protestants and Catholics, from the North and South, could meet and interact. For many respondents, this was the first opportunity to meet or discover the other and, almost in all cases, she found a substantial impact on the participants' identities.

\footnotetext{
3 Restorative nostalgia is about the nostos [return home] and could be understood as a kind of transhistorical reconstruction of a lost home. Whereas reflective nostalgia is grounded on algia; the longing itself, where return home is delayed. As Boym (2007) explains, "Nostalgia of the first type [restorative] gravitates toward collective pictorial symbols and oral culture. Nostalgia of the second type [reflective] is more oriented towards an individual narrative that savors details and memorial signs, yet perpetually defers homecoming itself." (Boym, 2007).
} 
Thus, socio-historical conditions of migration impact migrants' construction of emotions. In the case of refugees and asylum seekers, the conflict plays a central role in how they defined themselves and how others define them. However, there are some questions which arise from this view and should be explored in more depth; how does this construction of emotions (e.g., different types of nostalgia) intersect with their construction of belonging? How do these socio-historical conditions affect the construction of other emotions (e.g., empathy)? Here, it is vital to keep in mind that context matters; to understand the interaction between emotions and belonging we should consider the context in which the forced migration occurs because it has an essential impact on their construction of emotions after fleeing.

\subsubsection{The midway-to-nowhere scenario}

In addition to the socio-historical context, researchers of forced migration have also tried to understand decision-making and its implications for displacement and resettlement. They point to the refugees' perception of threat and danger in their home country (Jensen, 1966; Kunz, 1973). Seen from this perspective, refugees are pushed out; they do not move because of pull factors, at least in the case of those refugees who did not anticipate danger early. As a result, they move to search for a safe place, where they may spend a long time waiting. Chan and Loverridge's (1987) analysis of the psychological and the emotional life of Vietnamese in a refugee camp in Hong Kong, found that this period is significant in determining the initial orientation of the asylum seekers to the new country and the resettlement process. It contains fundamental changes in the life of asylum seekers. They explain: "If we are able to help people come to terms with their past - and thus with their present - we need to understand the part played in their current responses to themselves and the world around them by their experiences in the transit centers." (Chan \& Loverridge, 1987, p. 757). Other studies demonstrate that this period depletes the emotional resources severely and the coping ability of the refugee (Colic-Peisker \& Tilbury, 2003, p. 73). Usually, they start their journey by entering (illegally) a neighboring country, which has poor conditions, after which they tend to move to another country with better conditions. A good example is the case of those refugees who go to Indonesia and then to Australia or those who go to Turkey or Libya to arrive at a European country with good conditions. Exploring this period more profoundly leads to a better understanding of the newcomer's experience. 
Moreover, it should not be studied as a separate phase; it is a continuous process of flight and adjustment (Chan \& Loverridge, 1987; Lam, 1991).

Concerning belonging, many studies argue that it is during the midway-to-nowhere period that asylum seekers cannot develop a sense of belonging to the new place because of the uncertainty and the concentration only in the present without having a future plan (De Genova, 2002; Fuglerud, 1997). For Lam (1991), the refugee in this period is overwhelmed by a sense of non-belonging (Lam, 1991, p. 6). If the asylum seeker arrives with emotions, such as hate, anger, or fear toward his country of origin - as Jensen (1966) supposed - and if the psychological changes which occur in the 'transit' phase is fundamental for the whole process of resettlement, then what role do these emotions and changes play in resisting or pushing him toward belonging/or non-belonging once he arrives at his final destination, and in which directions? How does he make sense of this experience of being pushed out by the political regime or other groups that were supposed to offer him protection or at least consider him a citizen? Also, how does he remember, deal with, and value the past before flight?

\subsubsection{On the way scenario}

The first step after moving from the 'transit' process toward a new destination is to take transportation. Those in a good economic situation are more likely to gain a visa and therefore to enter the destination country directly and with relative ease. However, most refugees, especially the acute ones, in the words of Kunz (1973), lack these privileges. The only way to move is illegal. Thus, they are not only obligated to risk their lives and the lives of their family members, but they also become extremely vulnerable to smuggling networks. However, Hoffman's (2016) findings may challenge the view about the smuggler as a person who reaps advantages from their 'customers'; a small number of his informants have a positive view of their smugglers. They mention how some of them helped the asylum seekers to find a safe place, treated them with humanity and considered the safety of their customers as equal to their safety. This is especially common when the smugglers who accompany them are from their own country. What seems to be more questionable are the attitudes of the governments that focus on 'opportunism', rather than on compassion and empathy, as Nakhoul (2011) explains, "wishing to see a disaster unfold, in the hope of using it as a decisive deterrent to asylum seekers and smuggler alike” (As cited in Briskman \& Dimasi, 2016, p. 
264) or as Devetak (2004) describes the situation at the border where governments "wage a war" against the asylum seekers.

The on the way experience may become central for the construction of identity and memory in the diaspora. Interviews with survivors of Janga (a boat of asylum-seekers which sank off of the Australian coast) show how difficult it was for those survivors to go to the place of the tragedy; they did not wish to return there (Briskman \& Dimasi, 2016). Nguyen's (2016) study about Vietnamese who fled by boat demonstrates; "the sea and the boat, as sites of oceanic spatiality, enable Dinh and Le to (re)examen and construct definitive moments in Vietnamese/diaspora history in which identities, relationships, and belonging are determined "not by blood but by water"' (2016, p. 77).

Thus, I argue that more attention be given to social interaction which occurs on the way -- with the geographical location (particular spaces), police forces, NGO-workers, locals, other asylum seekers, passengers, and even with smugglers -- in order to understand its role in the subsequent process during the settlement. These interactions may have significant impacts on their interpretation of this experience because of the feeling of vulnerability, insecurity, and uncertainty that asylum-seekers live in these moments.

\subsubsection{Reception conditions in the destination country}

Many researchers reveal how reception conditions, or the way in which newcomers are treated after they arrive at their destination countries, including the "welcome" they receive, affects their emotions and sense of belonging whether it comes from state (Jenkins, 1991), media, or from their interactions with locals (Berry, 2012, p. 20; Wurie Khan, 2013, p. 119). A lack of empathy “increases the incomers' experience of non-belonging” (Svašek, 2010, p. 873, 2012, p. 9). Due to the feeling of exclusion and lack of sense of safety, scholars found that many Somali families do not feel that they belong to Denmark and they may embark on another migration (Valentine et al., 2009). Researchers also focus on the process of control in borders (Devetak, 2004; Marcu, 2014; McDermott Hughes, 1999), camps, or removal centers. They are also interested in the contact between locals, employees and professionals, objects on the one hand and asylum-seekers and refugees on the other; Sigfrid Gronseth (2012) found that the amulets, strings and ritual utensils which Tamils brought with them became objects that inspired new ways of belonging and participation in their new place. They make clear the problem of communication and how the needs of asylum-seekers are 
not always met due to misunderstanding from locals (Hall, 2012; Radford, 2012). Radford (2012) demonstrates how health-service providers are often ill-equipped to deal with their patients' emotional needs ${ }^{4}$. She also argues that many of the asylum-seekers feel that they have entered a "world populated by potential enemies, in the guise of social workers, doctors, legislators and government" (2012, p. 49). Hall (2012) analyzes the relationship between staff and newcomers in a British Immigration Removal Centre. She described the camp as "a place of emotions, politics and resistance, where fear and contempt are rife, but where empathy is never wholly effaced" (2012, p. 31). Focusing on encounters between refugees/asylum-seekers and more settled residents in Newcastle/England, Key Askins (2016) developed the concept 'emotional citizenry' as a "process, embedded in the complexities of places, lives and feelings, beyond claims to and exclusions from nationstatehood." Central issues in this process are social reciprocity (belonging relies on reciprocity) and the 'quest for recognition' (Askins, 2016).

However, the dynamics and outcomes of these interactions are more complicated than they appear and thus require more careful exploration (Bell, 2010; Rai, 2002): welcome, hospitality and solidarity are about power and superiority. They may challenge the construction of the forced migrants' feeling of belonging and raises the question about their perception of it, as well as their reactions. In addition, length of residence - one of the six factors which Antonsich (2010) considers vital to formulate the place-belongingness - may clash with personal experiences. The expression of comfortability and vulnerability in a place is not only related to the refugee's previous experience in this place (where negative social interactions occurred), but also in a similar place in their life experience (see Cuba \& Hummon, 1993; Sutherland, 2017). The material heritage or collective historical narrative may play a central role in evoking a sense of belonging and specific emotions; Finaly (2015) found 'belonging as feeling at home' among the Moroccan diaspora in Granada-Spain, mainly because of southern Spain's material (e.g., architectural) heritage. Still, he found emotions of loss and shame because of the way in which Granada is presented in religious history and collective memory. The role of memory and nostalgia could lead towards two

\footnotetext{
4 Need is theorized in different ways, but usually it refers to an existing gap between the patient's actual state and the optimal level of health (see Vivar \& McQueen, 2005). Emotional needs are an essential part of the care process (Halpern, 2003, p. 673), and they are related to culture and personal history. Displacement creates new needs because of the loss of status, alienation and marginalization (Radford, 2012, p. 39).
} 
opposite directions, as Rishbeth and Powell (2013) explain, "Memory appears to have a role in supporting an ongoing recognition and working out of how one might belong in a new place. Experiences of remembering landscapes can sometimes exacerbate the negative shock of the new, but can also be a restorative means of envisaging how everyday life continues beyond the strangeness" (2013, p. 175).

\subsubsection{The emotions, values, and tradition that accompany the refugee}

The most common approach to interaction with the new place and society comes from focusing on the forced migrant's mental health with a pathological or therapeutic perspective (see Albrecht, 2016; Wernesjö, 2014). This approach does not aid in accounting for the refugee's agency in this process. Refugees are portrayed as traumatized people motivated by their suffering of shame, humiliation, and anxiety, etc. Furthermore, this is based on predefined concepts without considering the migrants' interpretations and the meanings they give to their experience. This view makes it difficult to understand the specific needs of a subgroup of refugees which may arise from specific historical, cultural, and contextual challenges (Hsu et al., 2004). In addition, the presentation of refugees as traumatized people has negative implications for their future relations in the new place. Some researchers paid attention to the personal perspectives of the refugees and asylum seekers concerning their mental health status caused by their experience of trauma (Keyes \& Kane, 2004; Lyytinen, 2017; Pineteh, 2017; Watters, 2001; Whittaker et al., 2005). Keyes and Kane (2004) found that, in their new place, refugees search for empathy and reciprocity to "determine genuineness, trustworthiness, and to validate a sense of belonging." (2004, p. 819).

In addition to emotions, refugees bring with them their values, religion, and traditions. In general, when these issues are presented in forced migration studies, the interest is in its role in conflict settings and the politicization of religious identity or its role in coping with trauma (Gozdziak \& Shandy, 2002). For first-generation migrants, religion plays an essential role in social division (Daley, 2009) but also in providing the individual with an instrument for dealing with critical personal or situational challenges; what psychologists call Religious-Spiritual Coping (Ai et al., 2003; Bryant-Davis \& Wong, 2013). Forced migrants' traditional gastronomy provides a kind of connection through food (Brightwell das Graças, 2015). Some researchers found that religiosity, tradition, and values are also 
helpful for opening spaces of belonging in the new society (Chafic, 2010; Gozdziak \& Shandy, 2002; Taylor, 2009)

Therefore, I argue along with Albrecht (Albrecht, 2016, p. 29) that "aiming for the study in the field of a sociology of emotions that focuses on the general functions of emotions in interactions during the process of migration, none of the research done so far on this subject goes far enough. The potential of an accordant perspective has not been fully tapped yet." That is because emotions are not merely "convenient and occasional resources" which help to explain the transnational family, but are themselves "constitutive of the transnational family experience itself" (Skrbis, 2008, p. 236).

\section{Conclusion}

Unlike economic migrants or other kinds of voluntary migration, forced migrants decide to leave their country because their lives or the lives of one or more family members are threatened. This might be the result of war or political persecution at the hands of a totalitarian regime for example. However, even after leaving, this feeling of being threatened often remains. Sometimes this is because they have had to leave family members behind, who might remain in a dangerous situation, or who are subject to harassment by the state or other armed groups as a means of putting pressure on those who have escaped the country. The journey itself is often dangerous, and the refugee might have to attempt the journey numerous times before reaching his or her final destination. Many of them have experienced prison, torture, starving or other personal and extreme experiences. Perhaps they prefer to keep silent or avoid the verbal expressions of some emotions which accompany certain actions (such as shame or humiliation). Thus, exploring emotions among them is not as easy a task as it may appear.

When they arrive at their destination, they face various obstacles to reaching a new position in a new society. These obstacles might not only relate to the conditions of the host country itself but also the different rules of the game between 'there' and 'here.' Ignorance of these rules leads to exclusion. Familiarization of the unfamiliar becomes the most important strategy to overcome this strange or unknown situation or place, where the habitus has lost its ability to provide useful recommendations. Furthermore, 'capitals' are essential for participation in the new society. Emotions and values, which accompany forced migrants, are linked to the embodied cultural capital which is inherited (see Bourdieu, 
1986). Its modification takes time and effort because it is related to the socialization process. However, managing it becomes a central issue for constructing a home in the new place. What we can learn from migration studies about forced migrants' emotions could be summarized as follows;

1. They agree on the fundamental role of emotions in migration, something that classical theories have failed to do. Sociologists, therefore, need to develop more empirical research to obtain a better theoretical understanding of contemporary migratory movements.

2. They give more analytical prominence to the individual and his subjective sense in the process of immigration than in classical studies.

3. They usually put voluntary migrants and forced migrants in the same framework. When differentiating between them, mostly, they tend to study the emotions of forced migrants from a therapeutic or pathologic perspective (i.e., seeing them as traumatized people).

4. Most of the research on forced migration emotions and belonging could be described as fragmental and/or therapeutic; (1) the fragmental perspective looks at a specific phase of the migration journey, mostly, related to home and/or destination country. As a result, the consequences of the midway-to-nowhere and on the way, phases are almost ignored. (2) The therapeutic perspective tries to understand the implications of emotions, either in a specific step or in the whole experience of migration, for the forced migration engagement in the new destination, but are generally stuck with pathological or therapeutic perspectives. As a result, they ignore other functions of the forced migrant's emotions and contribute to enhancing the representation of refugees and asylum seekers as traumatized people, and herby depriving them of their agency.

5. They are fragmented; there is no integrated theory that explains the interaction between emotions and the constructed feeling of belonging after leaving home. While there is evidence that empathy influences the feeling of belonging in migration positively, we do not know how it happens; in which way and under which conditions it happens (see Wernesjö, 2014). A recent study based on ritual theory found that activity and practices in dance clubs fail to develop solidarity and sense of belonging because, interviewees valued a different style of involvement and interaction and they expressed otherness rather than solidarity (Peperkamp, 2018). In summary, more in- 
depth research is required about the way in which forced migrants perceive their situation, as well as their involvement, interactions, and other factors that intersect with this perception. More attention should be given to the path a specific emotion follows to contribute to producing a feeling of belonging; values are strictly related to emotions and forced migrants' values are usually approached as something that restricts belonging in the host country. This could be attributed to the dominance of the 'clash of the civilizations' theory among research on the Arab and Islamic world; countries from which most of the refugees and asylum seekers in Europe come (Robila, 2018). There is still little research on the role of emotions in shaping the values and value commitments in forced migration context and their feeling of belonging.

\section{References}

Ai, A. L., Peterson, C., \& Huang, B. (2003). The Effect of Religious-Spiritual Coping on Positive Attitudes of Adult Muslim Refugees From Kosovo and Bosnia. International Journal for the Psychology of Religion, 13(1), 29-47. https://doi.org/10.1207/S15327582IJPR1301_04

Al-Ali, N., \& Koser, K. (2003). New approaches to migration?: Transnational communities and the transformation of home. London and New York: Routledge. https://doi.org/10.4324/9780203167144

Albrecht, Y. (2016). Emotions in Motion: How feelings are considered in the scope of migration sociological studies. Digithum, (18).

Antoniadou, M. (2019). "Can I join you?” Refugees’ Emotion Regulation Experiences during Resettlement. Journal of Business \& Economic Policy, 7(2). https://doi.org/10.30845/jbep.v7n2p3

Antonsich, M. (2010). Searching for belonging - An analytical framework. Geography Compass. https://doi.org/10.1111/j.1749-8198.2009.00317.x

Appadurai, A. (1996). Modernity at Large: Cultural Dimensions of Globalisation. Public Worlds, 1, 229. https://doi.org/316.722 APP

Asad, T. (2003). Formations of the Secular: Christianity, Islam, modernity. Stanford, California: Stanford University Press. 
Revista Internacional de Estudios Migratorios, 2021, Vol. 11(1), pp. 27-58.

Askins, K. (2016). Emotional citizenry: everyday geographies of befriending, belonging and intercultural encounter. Transactions of the Institute of British Geographers, 41(4), 515-527. https://doi.org/10.1111/tran.12135

Banerjee, B. (1983). Social Networks in the Migration Process: Empirical Evidence on Chain Migration in India. Source: The Journal of Developing Areas The Journal of Developing Areas, 17(17), 185-196. Retrieved from http://www.jstor.org/stable/4191118\%5Cnhttp://about.jstor.org/terms

Basch, L. G., Glick Schiller, N., \& Szanton Blanc, C. (1994). Nations unbound: transnational projects, postcolonial predicaments, and deterritorialized nation-states. New York (Vol. 22). https://doi.org/10.1525/ae.1995.22.3.02a00330

Baškauskas, L. (1981). The Lithuanian Refugee Experience and Grief. The International Migration Review, 15(1/2), 276-291.

Bell, A. (2010). Being "at home" in the nation: Hospitality and sovereignty in talk about immigration. Ethnicities, 1O(2), 236-256. https://doi.org/10.1177/1468796810361653

Berry, S. (2012). Integrating Refugees: The Case for a Minority Rights Based Approach. International Journal of Refugee Law, 24(1). Retrieved from https://doi.org/10.1093/ijrl/eero38

Blažytė, G., Frëjutė-Rakauskienè, M., \& Pilinkaitè-Sotirovič, V. (2020). Policy and media discourses on refugees in Lithuania: shaping the boundaries between host society and refugees. OIKOS: Lietuviu Migracïos Ir Diasporos Studijos, 1(29), 7-30. https://doi.org/https://doi.org/10.7220/2351-6561.29.1

Bonifacio, T. (2017). (Mis)Givings in a Prairie City? Identity and Belonging of Filipina (Im)Migrants in Lethbridge, Alberta. In G. Bonifacio \& J. Drolet (Eds.), Canadian Perspectives on Immigration in Small Cities. 77-98: Springer International Publishing Switzerland. https://doi.org/10.1007/978-3-319-40424-0

Boswell, C. (2002). Addressing the causes of migratory and refugee movements: the role of the European Union. Retrieved from http://www.unhcr.org/3e19ac624.pdf

Bourdieu, P. (1986). The Forms of Capital. In The Forms of Capital (pp. 280-291). https://doi.org/10.1017/CBO9781107415324.004

Boyd, M. (1989). Family and Personal Networks in International Migration: Recent Developments and New Agendas. International Migration Review, 23(3), 638. 
https://doi.org/10.2307/2546433

Boym, S. (2007). Nostalgia and Its Discontents. The Hedgehog Review.

Brickell, K, \& Datta, A. (2012). Translocal Geographies: Spaces, Places, and connections. Population, Space and Place, 18(5), 669-67o. https://doi.org/10.1002/psp.693

Brightwell das Graças, M. (2015). Diasporic Reconnections through Food. In A. Christou \& E. Mavroudi (Eds.), Dismantling Diasporas: Rethinking the Geographies of Diasporic Identity, Connection and Development (pp. 29-42). London: Routledge.

Briskman, L., \& Dimasi, M. (2016). Re-living Janga: Survivor Narratives. In L. Mannik (Ed.), Migration by boat: discourses of trauma, exclusion, and survival (pp. 251-268). New York: Berghahn Books.

Brown, J. (2011). Expressions of diasporic belonging: The divergent emotional geographies of Britain's Polish communities. Emotion, Space and Society, 4(4), 229-237. https://doi.org/10.1016/j.emospa.2011.01.004

Bryant-Davis, T., \& Wong, E. C. (2013). Faith to Move Mountains: Religious coping, spirituality, and interpersonal trauma recovery. American Psychologist, 68(8), 675684. https://doi.org/10.1037/aoo34380

Burrell, K. (2003). Small-scale transnationalism: Homeland connections and the Polish "community" in Leicester. International Journal of Population Geography, 9(4), 323335. https://doi.org/10.1002/ijpg.290

Castles, S., Haas, H. De, \& Miller, M. (2014). The age of migration: International population movements in the modern world. Palgrave Macmillan.

Chafic, W. (2010). On Being Part of the Whole: Positioning the Values of Muslim Men in Sydney. In T. Bonifacio \& V. Angeles (Eds.), Gender, religion, and migration: pathways of integration (pp. 55-70). Lanham u.a.: Lexington Books.

Chaloyan, A. (2017). Fluctuating Transnationalism. Springer Fachmedien Wiesbaden.

Chan, K., \& Loverridge, D. (1987). Refugees ' in Transit ': Vietnamese in a Refugee Camp in Hong Kong. Migration Review, 21(3), 745-759. https://doi.org/10.2307/2546620

Colic-Peisker, V., \& Tilbury, F. (2003). "Active” and "passive" resettlement: The influence of support services and refugees' own resources on resettlement style. International Migration, 41(5), 61-92. https://doi.org/10.1111/j.0020-7985.2003.00261.x

Courgeau, D. (1995). Migration theories and behavioural models. International Journal of 
Revista Internacional de Estudios Migratorios, 2021, Vol. 11(1), pp. 27-58.

Population Geography, 1(1), 19-27. https://doi.org/10.1002/ijpg.6060010103

Cuba, L., \& Hummon, D. M. (1993). Constructing a sense of home: Place affiliation and migration across the life cycle. Sociological Forum, 8(4), 547-572. https://doi.org/10.1007/BFo1115211

Daley, C. (2009). Exploring community connections: Community cohesion and refugee integration at a local level. Community Development Journal, 44(2), 158-171. https://doi.org/10.1093/cdj/bsmo26

Datta, A. (2011). geographies of London: Belonging and "otherness" among Polish migrants after 2004. In Katherine Brickell \& A. Datta (Eds.), Translocal Geographies: Spaces, Places, Connections (pp. 73-92). Ashgate Publishing Limited.

De Genova, N. P. (2002). Migrant "Illegality" and Deportability in Everyday Life. Annual Review of Anthropology, 31(1), 419-447. https://doi.org/10.1146/annurev.anthro.31.040402.085432

De Jong, G. F., Abad, R. G., Arnold, F., Carino, B. V., Fawcett, J. T., \& Gardner, R. W. (1983). International and Internal Migration Decision Making: A Value-Expectancy Based Analytical Framework of Intentions to Move from a Rural Philippine Province. International Migration Review, 17(3), 470-484. https://doi.org/10.2307/2545798

De Jong, G. F., \& Fawcett, J. T. (1981). Motivations for Migration: An Assessment and a Value-Expectancy Research Model. In Migration Decision Making (pp. 13-58). https://doi.org/10.1016/B978-0-08-026305-2.50008-5

Devetak, R. (2004). In fear of refugees: the politics of Border Protection in Australia. The International Journal of Human Rights, 8(1), 101-109. https://doi.org/10.1080/1364298042000212565

Eisenberg, N. (2000). Emotion, Regulation, and Moral Development. Annual Review of Psychology, 51(1), 665-697. https://doi.org/10.1146/annurev.psych.51.1.665

Eltokhy, S. (2020). Towards Belonging: Stability and Home for Syrian Refugee Women in Milan. Journal of Identity and Migration Studies, 14(1).

Faist, T. (1997). The Crucial Meso-Level. International Migration, Immobility and Development: $\quad$ Multidisciplinary $\quad$ Perspectives, $187-218$. https://doi.org/10.1002/(SICI)1099-1220(199905/06)5:3<238::AIDIJPG133>3.0.CO;2-C 
Falicov, C. J. (2005). Emotional transnationalism and family identities. Family Process. https://doi.org/10.1111/j.1545-5300.2005.00068.x

Finaly, R. (2015). Narratives of Belonging: The Moroccan Diaspora in Granada, Spain. In A. Christou \& E. Mavroudi (Eds.), Dismantling Diasporas: Rethinking the Geographies of Diasporic Identity, Connection and Development (pp. 43-56).

Fuglerud, Ø. (1997). Ambivalent incorporation: Norwegian policy towards Tamil Asylumseekers from Sri Lanka. Journal of Refugee Studies, 10(4), 443-461. https://doi.org/10.1093/jrs/10.4.443

Glick Schiller, N., Basch, L., \& Blanc-Szanton, C. (1992). Transnationalism: A new analytic framework for understanding migration. Annals of the New York academy of sciences, 645(1), 1-24.

Galasińska, A. (2010). Gossiping in the polish club: An emotional coexistence of "old" and "new" migrants. Journal of Ethnic and Migration Studies, 36(6), 939-951. https://doi.org/10.1080/13691831003643363

Gozdziak, E. M., \& Shandy, D. J. (2002). Editorial Introduction: Religion and Spirituality in Forced Migration. Journal of Refugee Studies, 15(2). https://doi.org/10.1093/jrs/15.2.129

Hage, G. (1997). At Home in the Entrails of the West: Multiculturalism, Ethnic Food and Migrant Home-Building. In Home/World: Space, Community and Marginality in Sydney's West (pp. 99-153).

Hagen-Zanker, J. (2008). Why do people migrate? A review of the theoretical literature. A Review of the Theoretical Literature (January ..., (January), 1-25. https://doi.org/10.2139/ssrn.1105657

Haidt, J., Koller, S. H., \& Dias, M. G. (1993). Affect, culture, and morality, or is it wrong to eat your dog? Journal of Personality and Social Psychology, 65(4), 613-628. https://doi.org/10.1037/0022-3514.65.4.613

Hall, A. (2012). "these people could be anyone": Fear, contempt (and empathy) in a britich immigration removal centre. In M. Svašek (Ed.), Emotions and human mobility: Ethnographies of movement (pp. 17-34). Routledge.

Halpern, J. (2003). What is clinical empathy? Journal of General Internal Medicine, 18(8), 670-674. 
Halse, C. (2018). Theories and Theorising of Belonging. In C. Halse (Ed.), Interrogating Belonging for Young People in Schools. London: PALGRAVE.

Herrero-Arias, R., Hollekim, R., Haukanes, H., \& Vagli, A. (2020). The emotional journey of motherhood in migration. The case of Southern European mothers in Norway. Migration Studies. https://doi.org/10.1093/migration/mnaaoo6

Hoffman, S. (2016). "if we die, we die together": Risking death at sea in search of saftey. In L. Mannik (Ed.), Migration by boat: discourses of trauma, exclusion, and survival (pp. 219-234). New York: Berghahn Books.

Hsu, E., Davies, C. A., \& Hansen, D. J. (2004). Understanding mental health needs of Southeast Asian refugees: Historical, cultural, and contextual challenges. Clinical Psychology Review. https://doi.org/10.1016/j.cpr.2003.10.003

Hugo, G. J. (1981). Village-Community Ties, Village Norms, and Ethnic and Social Networks: A Review of Evidence from the Third World. Migration Decision Making: Multidisciplinary Approaches to Microlevel Studies in Developed and Developing Countries (Vol. 14). https://doi.org/10.1016/B978-0-08-026305-2.50013-9

Huizinga, R. P., \& van Hoven, B. (2018). Everyday geographies of belonging: Syrian refugee experiences in theNorthern Netherlands. Geoforum, (96), 309-317.

Jenkins, J. H. (1991). The state construction of affect: Political ethos and mental health among Salvadoran refugees. Culture, Medicine and Psychiatry, 15(2), 139-165. https://doi.org/10.1007/BFo0119042

Jensen, F. (1966). Psychological Aspects of the Social Isolation of Refugees. The International Migration Digest, 3(1), 40-60.

Joas, H. (2000). The genesis of values. University of Chicago Press.

Kale, A., Kindon, S., \& Stupples, P. (2020). 'I Am a New Zealand Citizen Now-This Is My Home': Refugee Citizenship and Belonging in a Post-colonizing Country. Journal of Refugee Studies. https://doi.org/10.1093/jrs/feyo6o

Keyes, E. F., \& Kane, C. F. (2004). Belonging and adapting: Mental health of Bosnian refugees living in the United States. Issues in Mental Health Nursing, 25(8), 809-831. https://doi.org/10.1080/01612840490506392

Kläger, F., \& Stierstorfer, K. (Eds.). (2016). Diasporic Constructions of Home and Belonging. Berlin/Boston: Walter de Gruyter GmbH. 
Kochan, D. (2016). Home is where I lay down my hat? The complexities and functions of home for internal migrants in contemporary China. Geoforum, 71, 21-32. https://doi.org/10.1016/j.geoforum.2016.02.021

Kunz, E. . F. (1973). The refugee In Flight: Kinetic Models And Forms Of Dispacement. International Migration Review, 7(2), 125-146. https://doi.org/10.2307/3002424

Lam, L. (1991). Vietnamese "boat people" in Hong Kong: transition to nowhere. Centre for refugee studies.

Leith, K. H. (2006). “Home is where the heart is...or is it?”. A phenomenological exploration of the meaning of home for older women in congregate housing. Journal of Aging Studies, 2O(4), 317-333. https://doi.org/10.1016/j.jaging.2005.12.002

Lewis, A. (1954). Economic Development with Unlimited Supplies of Labour. The Manchester School, 22(2), 139-191. https://doi.org/10.1111/j.14679957.1954.tbooo21.x

Liu, L. S. (2014). A search for a place to call home: Negotiation of home, identity and senses of belonging among new migrants from the People's Republic of China (PRC) to New Zealand. Emotion, Space and Society, 1O(1), 18-26. https://doi.org/10.1016/j.emospa.2013.01.002

Lyytinen, E. (2017). Refugees' “journeys of trust": Creating an analytical framework to examine refugees' exilic journeys with a focus on trust. Journal of Refugee Studies, 30(4), 489-510. https://doi.org/10.1093/jrs/few035

Marcu, S. (2014). Geography of belonging: nostalgic attachment, transnational home and global mobility among Romanian immigrants in Spain. Journal of Cultural Geography, 31(3), 326-345. https://doi.org/10.1080/o8873631.2014.945719

Marlowe, J. (2017). Belonging and Transnational Refugee Settlement: Unsettling the Everyday and the Extraordinary. Taylor and Francis.

Massey, D. S., Arango, J., Hugo, G., Kouaouci, A., Pellegrino, A., \& Taylor, J. E. (1993). Theories of International Migration: A Review and Appraisal. Population and Development Review, 19(3), 431. https://doi.org/10.2307/2938462

McDermott Hughes, D. (1999). Refugees and squatters: Immigration and the politics of territory on the Zimbabwe-Mozambique border. Journal of Southern African Studies, 25(4), 533-552. https://doi.org/10.1080/030570799108461 
Nakhoul, G. (2011). Overboard: You would not believe what really triggered Australia's controversial policy on boat people. Merrylands: Dar Meera.

Nguyen, V. (2016). Nouc/Water: Oceanic spatiality and the Vietnamese diaspora. In L. Mannik (Ed.), Migration by boat: discourses of trauma, exclusion, and survival (pp. 65-79). New York: Berghahn Books.

Nolin, C. (2006). Transnational Ruptures: Gender and Forced Migration. Burlington,: Ashgate Publishing Limited.

Parker, S. (2020). 'Just eating and sleeping': asylum seekers' constructions of belonging within a restrictive policy environment. Critical Discourse Studies. https://doi.org/10.1080/17405904.2018.1546198

Parsell, C. (2012). Home is Where the House is: The Meaning of Home for People Sleeping Rough. Housing $\quad$ Studies, $\quad 27(2), \quad 159-173$. https://doi.org/10.1080/02673037.2012.632621

Peperkamp, E. (2018). 'Dutch don't dance' - leisure experiences and sense of belonging among Polish migrants in the Netherlands. Leisure Studies, 37(3), 256-267.

Petersen, W. (1958). A General Typology of Migration. American Sociological Review, 23(3), 256. https://doi.org/10.2307/2089239

Pineteh, E. (2017). Moments of suffering, pain and resilience: Somali refugees' memories of home and journeys to exile. Cogent Social Sciences, 3 .

Piore, M. (1979). Birds of Passage: Migrant Labor and Industrial Societies. Cambridge: the University Press.

Radford, K. (2012). "Unkind cuts": Health policy and practice versus the health and emotional well-being of asylum-seekers and refugees in Ireland. In M. Svašek (Ed.), Emotions and human mobility: Ethnographies of movement (pp. 35-51). Routledge. https://doi.org/10.1080/13691831003643348

Rai, A. (2002). Rule of sympathy. New York: PALGRAVE.

Ranis, G., \& Fei, J. C. H. (1961). A Theory of Economic Development. The American Economic Review, 51(4), 533-565. https://doi.org/10.2307/1812785

Riaño-Alcalá, P. (2008). Journeys and landscapes of forced migration: Memorializing fear among refugees and internally displaced Colombians. Social Anthropology. https://doi.org/10.1111/j.1469-8676.2008.00036.x 
Richmond, A. (1988). Sociological theories of international migration: the case of refugees. $\begin{array}{llll}\text { Current Sociology. } & \text { Retrieved }\end{array}$ http://journals.sagepub.com/doi/pdf/10.1177/o01139288036002004

Rishbeth, C., \& Powell, M. (2013). Place Attachment and Memory: Landscapes of Belonging as Experienced Post-migration. Landscape Research, 38(2), 160-178. https://doi.org/10.1080/01426397.2011.642344

Robila, M. (2018). Refugees and Social Integration in Europe. Retrieved from https://www.un.org/development/desa/family/wpcontent/uploads/sites/23/2018/o5/Robila_EGM_2018.pdf

Sigfrid Gronseth, A. (2012). Moving Tamils, Moving Amulets. In M. Svašek (Ed.), Moving subjects, moving objects. Berghahn Books.

Sjaastad, L. A. (1962). The Costs and Returns of Human Migration. Journal of Political Economy, 7o(5, Part 2), 80-93. https://doi.org/10.1086/258726

Skrbis, Z. (2008). Transnational families: Theorising migration, emotions and belonging. $\begin{array}{llll}\text { Journal of } & \text { Intercultural } & \text { Studies, } & \text { 29(3), }\end{array}$ https://doi.org/10.1080/07256860802169188

Sutherland, C. (2017). Sense of Place Amongst Immigrant and Refugee Women in Kingston and Peterborough, Ontario. In G. Bonifacio \& J. Drolet (Eds.), Canadian Perspectives on Immigration in Small Cities. Springer International Publishing Switzerland.

Svašek, M. (2010). On the move: Emotions and human mobility. Journal of Ethnic and Migration Studies, 36(6), 865-880. https://doi.org/10.1080/13691831003643322

Svašek, M. (2012). Emotions and human mobility: Key concerns. In M. Svašek (Ed.), Emotions and human mobility: Ethnographies of movement (pp. 1-16). Routledge.

Taylor, H. (2009). Narratives of loss, longing and daily life: The meaning of home for Cypriot refugees in London. University of East London. Retrieved from http://roar.uel.ac.uk/3928/1/532990.pdf

Todaro, M. P. (1969). A Model of Labor Migration and Urban Unemployment in Less Developed Countries. The American Economic Review, 59(1), 138-148. https://doi.org/10.2307/1811100

Trew, J. D. (2007). Negotiating identity and belonging: Migration narratives of protestants from Northern Ireland. Immigrants and Minorities, 25(1), 22-48. 
Revista Internacional de Estudios Migratorios, 2021, Vol. 11(1), pp. 27-58.

https://doi.org/10.1080/02619280701630938

Trew, J. D. (2010). Reluctant diasporas of northern Ireland: Migrant narratives of home, conflict, difference. Journal of Ethnic and Migration Studies, 36(4), 541-560. https://doi.org/10.1080/13691830903520424

Valentine, G., Sporton, D., \& Nielsen, K. B. (2009). Identities and belonging: A study of Somali refugee and asylum seekers living in the UK and Denmark. Environment and Planning D: Society and Space, 27(2), 234-250. https://doi.org/10.1068/d3407

Vaqari, D. (2020). Transnationalism and migration: the concept of home in postcommunist Albanian diasporas. University of Derby. Retrieved from https://derby.openrepository.com/handle/10545/624783

Vishkin, A., Schwartz, S. H., Ben-Nun Bloom, P., Solak, N., \& Tamir, M. (2020). Religiosity and Desired Emotions: Belief Maintenance or Prosocial Facilitation? Personality and Social Psychology Bulletin. https://doi.org/10.1177/0146167219895140

Vivar, C. G., \& McQueen, A. (2005). Informational and emotional needs of long-term survivors of breast cancer. Journal of Advanced Nursing. https://doi.org/10.1111/j.1365-2648.2005.03524.x

Von Scheve, C. (2015). Societal origins of values and evaluative feelings. In T. Brosch \& D. Sander (Eds.), Handbook of Value: Perspectives from Economics, Neuroscience, Philosophy, Psychology and Sociology (pp. 175-195).

Vuolteenaho, J., \& Lyytinen, E. (2018). Reflections on the variations and spatialities of (un)welcome - Commentary to gill. Fennia. https://doi.org/10.11143/fennia.70290

Wallerstein, I. (1974). The Modern World System. Theory, Culture \& Society (Vol. 7).

Walsh, K. (2012). Emotion and migration: British transnationals in Dubai. Environment and Planning D: Society and Space, 3o(1), 43-59. https://doi.org/10.1068/d12409

Wang, B. (2016). Emotions and home-making: Performing cosmopolitan sociability among first generation new Chinese migrants in New Zealand. Asian and Pacific Migration Journal, 25(2), 130-147. https://doi.org/10.1177/0117196816639058

Watters, C. (2001). Emerging paradigms in the mental health care of refugees. Social Science and Medicine. https://doi.org/10.1016/So277-9536(oo)00284-7

Wernesjö, U. (2014). Conditional Belonging: Listening to Unaccompanied Young Refugees 'Voices. Digital Comprehensive Summaries of Uppsala Dissertations from the Faculty 
of Social Sciences. Uppsala: Acta Universitatis Upsaliensis. (Vol. 93).

Wettergren, Å. (2013). A Normal Life: Reception of Asylum Seekers in an Italian and a Swedish Region.

Whittaker, S., Hardy, G., Lewis, K., \& Buchan, L. (2005). An exploration of psychological well-being with young Somali refugee and asylum-seeker women. Clinical Child Psychology and 10(2), Psychiatry, 196. https://doi.org/10.1177/1359104505051210

Wimalaratana, W. (2016). International Migration and Migration Theories. Social Affairs, $1(5), 13-32$.

Wolf, D. (2002). There's no place like 'home': emotional transnationalism and the struggles of second-generation Filipinos. In P. Levitt \& M. Waters (Eds.), The changing face of home: The transnational lives of the second generation (pp. 255-294). Russell Sage Foundation.

Wurie Khan, A. (2013). The Relations between Asylum Seekers/Refugees' Belonging \& Identity Formations and Perceptions of the Importance of UK Press. The University of Edinburgh.

Yildiz, U. (2017). Tracing Asylum Journeys: Transnational Refugee Mobility to Canada via Turkey. Carleton University. 